\title{
Women's Health: Most Common Physiologic and Pathologic Cutaneous Manifestations During Pregnancy
}

\author{
Azhar M. Barnawi ${ }^{1}$, Ghassan M. Barnawi ${ }^{2}$, Awadh M. Alamri ${ }^{2}$ \\ 1. Family Medicine, Armed Forces Hospital, Prince Mansour Military Hospital for Community Medicine, Taif, SAU 2. \\ Dermatology, College of Medicine at King Saud bin Abdulaziz University for Health Sciences, King Abdulaziz Medical \\ City, Jeddah, SAU
}

Corresponding author: Azhar M. Barnawi, dr.azhar.barnawi@gmail.com

\begin{abstract}
Pregnant women are susceptible to various physiological and pathological skin and body habitus changes during pregnancy due to the alterations that occur in a multi-organ-system fashion. Pregnancy can be the onset of different dermatological diseases and can exacerbate pre-existing cutaneous conditions. Moreover, management of dermatologic diseases during pregnancy might be challenging as it requires special attention to both mother and fetus. We aim to assess the most common cutaneous changes and conditions that occur during pregnancy by reviewing the previous studies conducted on this subject.
\end{abstract}

The medical literature was explored through PubMed and Google scholar databases starting from 2015 to 2021. The included searching terms were a combination of "Cutaneous changes and pregnancy," Dermal conditions and pregnancy," Pregnancy-associated dermal conditions," and "Dermatological changes and pregnant women." The inclusion criteria included original articles conducted on pregnant women and full text- articles.

A total of 134 articles were obtained, 11 articles were eligible for the inclusion criteria. The 11 studies included a total number of 14,813 pregnant women and covered four countries. The most common cutaneous conditions experienced by pregnant women were primarily physiological skin changes, pregnancy-specific dermatopathologies, and exacerbations of other common skin diseases.

All in all, this systematic review concluded that pregnant women are more vulnerable to various dermatological conditions during pregnancy. These changes were more commonly physiological such as hyperpigmentations. However, pathological pregnancy-specific skin conditions and exacerbations of preexisting dermatoses like atopic eruptions were also reported.

Review began 07/05/2021 Review ended 07/12/2021 Published 07/21/2021

(c) Copyright 2021 Barnawi et al. This is an open access article distributed under the terms of the Creative Commons Attribution License CC-BY 4.0., which permits unrestricted use, distribution, and reproduction in any medium, provided the original author and source are credited.
Categories: Dermatology, Obstetrics/Gynecology

Keywords: cutaneous, changes, common, pregnancy, a systematic review

\section{Introduction And Background}

Pregnancy is associated with multiple physiological changes involving different organ systems like the endocrine, vascular, metabolic, and immune systems of gravid women resulting in several cutaneous changes which can be physiological or pathological [1]. These conditions are due to physiological changes, specific dermatoses of pregnancy, and other common pregnancy non-specific skin diseases in pregnancy [2].

Physiological skin changes during pregnancy primarily involve alterations in the degree of skin pigmentation and skin laxity mainly due to the effect of the elevated hormones [3]. Pregnancy-specific dermatologic pathologies involve impetigo herpetiformis, cholestasis of pregnancy, prurigo of pregnancy, pruritic folliculitis, pruritic urticarial papules, and plaques of pregnancy. Moreover, other existed skin conditions, such as psoriasis and atopic dermatitis, may worsen and present with flares during pregnancy $[4,5]$. However, improvement in some dermatological skin diseases during pregnancy can also be seen [6].

Pregnant women are mostly aware of most of the common physiological skin changes that occur during pregnancy, and they commonly tend to seek medical advice for actual new-onset pathological skin conditions or exacerbations of pre-existing inflammatory skin disorders [2]. However, the presentation of many dermatological diseases during pregnancy can vary and may have atypical presentation; for example, itching can occur in one among five normal pregnancies, but it can be the presenting symptom of several pregnancy dermatoses. Therefore, the accurate diagnosis of various dermal conditions during pregnancy can be difficult [2]. In addition, pregnancy can change the management of these common skin conditions and make it more challenging; these challenges are mostly related to the safety and harm of medications and other interventions like laser therapy to the developing fetus [2]. Therefore, we conducted this review of the literature to evaluate and discuss the various pregnancy-related dermatological conditions. 


\section{Review}

\section{Method}

The PRISMA checklist guidance for systematic review and meta-analysis [7] was followed to write this systematic review. The two databases: PubMed and Google scholar databases were revised searching for literature articles. The eligible research articles between 2015 and 2021 were selected.

\section{Search strategy}

Several keywords were used for searching purposes, including a combination of "Cutaneous changes and pregnancy," "Dermal conditions and pregnancy," “pregnancy-associated dermal conditions,” and "Dermatological changes and pregnant women." All the titles and abstracts produced from this primary exploration were revised thoroughly to prevent missing potential studies. The findings were then examined to choose only original research articles evaluating the dermatological changes during pregnancy. All fulltext articles written in English were defined as articles of relevance, which were then included in the second stage.

\section{Eligibility criteria}

The second step was deciding on the inclusion criteria to select the eligible studies. Abstracts were assessed manually to select the relevant studies for revision. The inclusion criteria were studies conducted on pregnant women and investigated the physiological changes and cutaneous conditions during pregnancy. Reviews and studies that had incomplete or overlapped data were excluded. Also, unavailable full-text articles or inappropriate study designs were excluded. The full description of the search strategy is shown in Figure 1 .

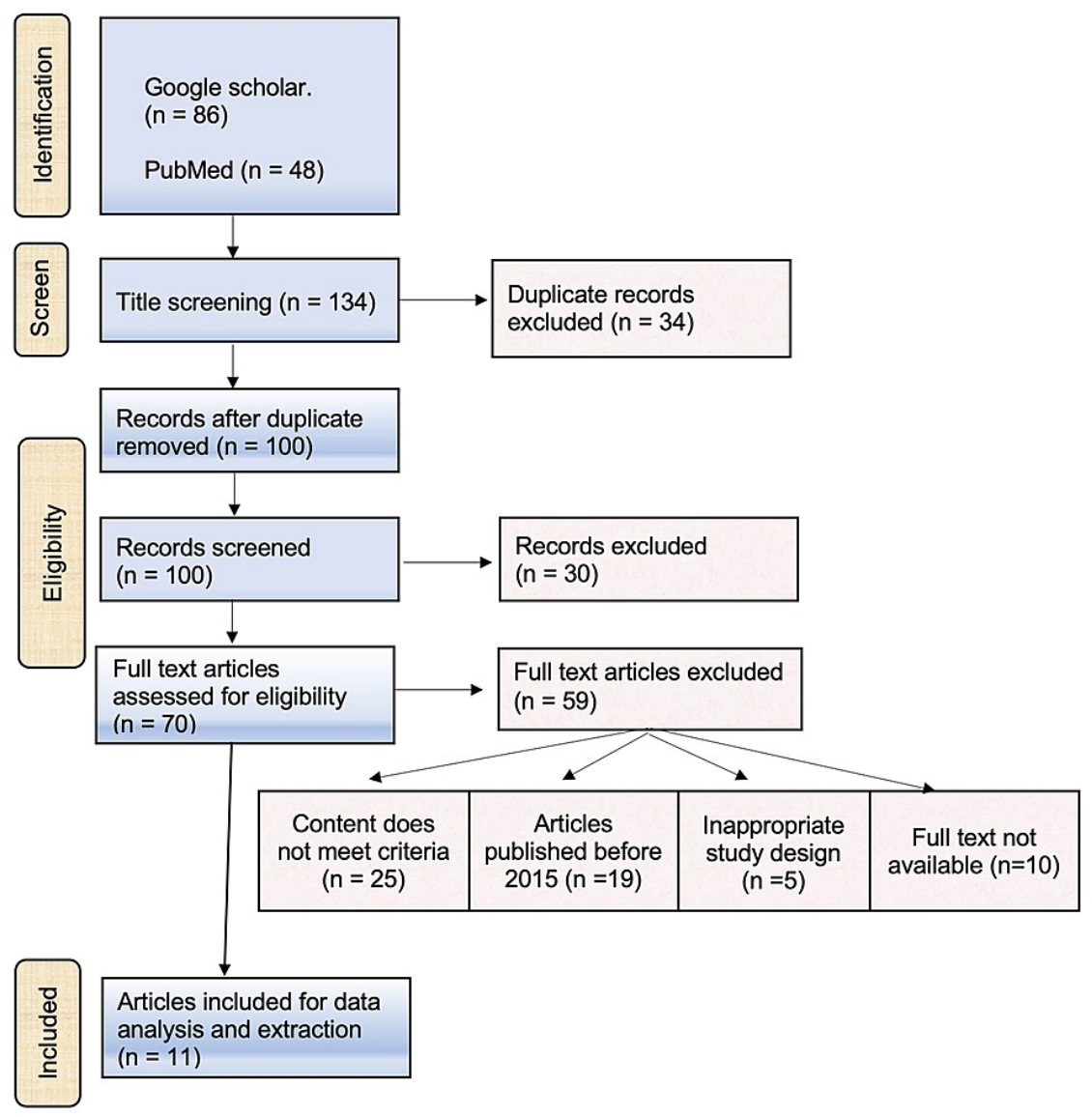

FIGURE 1: Planning of eligible criteria

\section{Data review and analysis}

A specially designed excel sheet was used for data extraction. The chosen data from eligible research articles were then revised via the excel sheet. Any research articles published by one research group examining similar variables were reviewed for any potential duplication. 


\section{Cureus}

\section{Results}

This systematic review included 11 articles that met the eligibility criteria and were published between 2015 and 2021 (Table 1) [8-18]. In regard to the study designs of included articles, there were two cross-sectional studies [14,18], three cross-sectional were observational studies [10,16,17], one observational [8], one prospective observational cohort [9], one retrospective [11], and one prospective [13] whereas one study did not specify the design [12]. The total number of participants in the 11 studies was 14,813 participants, the least number of subjects included in a study was 100 pregnant women [12], and the largest number included was 9,679 [8]. The included studies were conducted in only four countries; one study in Nigeria [9], one study in Libya [13], one study in Brazil [18], whereas the remaining eight studies were all in India [8,10$12,15-17]$. The overall major dermatological conditions during pregnancy were physiological skin changes [11-18] and pregnancy-specific dermatopathologies [8,9]. However, only one study reported that STDs and other infectious skin disorders were the major presenting dermatosis during pregnancy [10].

\begin{tabular}{|c|c|c|c|c|c|}
\hline $\begin{array}{l}\text { Author and } \\
\text { Publication } \\
\text { year }\end{array}$ & Study design & $\begin{array}{l}\text { Population, } \\
\text { Sample size }\end{array}$ & Country & $\begin{array}{l}\text { The most common } \\
\text { manifestation/change }\end{array}$ & Results and main findings \\
\hline $\begin{array}{l}\text { Deora et al. } \\
2021 \text { [8] }\end{array}$ & Observational & $\begin{array}{l}-9,679 \\
\text { pregnant } \\
\text { women }\end{array}$ & India & $\begin{array}{l}\text {-Specific dermatoses } \\
40.85 \%\end{array}$ & $\begin{array}{l}{ }^{*} 164(1.69 \%) \text { had various skin disorders }{ }^{*} 67 \\
(40.85 \%) \text { of them had specific dermatoses of } \\
\text { pregnancy }{ }^{*} \text { Prurigo of pregnancy }(49.12 \%) \text { of the } \\
\text { cases with specific dermatoses, pruritic urticarial } \\
\text { plaques and papules of pregnancy }(43.93 \%), \\
\text { pruritus gravidarum }(6.06 \%) \text {, Pemphigoid } \\
\text { gestationalis }(1.2 \%)\end{array}$ \\
\hline $\begin{array}{l}\text { Ayanlowo et } \\
\text { al. } 2020 \text { [9] }\end{array}$ & $\begin{array}{l}\text { Prospective } \\
\text { observational } \\
\text { cohort }\end{array}$ & $\begin{array}{l}-296 \text { pregnant } \\
\text { women }\end{array}$ & $\begin{array}{l}\text { Nigeria } \\
\text { (West } \\
\text { Nigeria) }\end{array}$ & $\begin{array}{l}\text {-Signs of dermatoses } \\
85.5 \%\end{array}$ & $\begin{array}{l}\text { *Itching } 42.2 \% \text {, signs of dermatoses } 85.5 \%{ }^{*} 3.7 \% \\
\text { Specific dermatoses; Atopic eruption of } \\
\text { pregnancy (AEP) }(72.72 \% \% \text { ) and pruritic urticarial } \\
\text { papules and plaques of pregnancy were seen in } \\
(27.27 \%){ }^{*} \text { The most common non-specific } \\
\text { pregnancy dermatoses were acne vulgaris } \\
(43.6 \%) \text {, superficial fungal infections ( } 40.2 \%) \text { and } \\
\text { melasma ( } 8.6 \%) \text {. } \text { A background history of atopic } \\
\text { dermatitis was significantly associated with AEP. } \\
\text { *skin conditions are common in pregnancy; fatal } \\
\text { pregnancy dermatoses were not seen in this } \\
\text { study. }\end{array}$ \\
\hline $\begin{array}{l}\text { Choudhary } \\
\text { et al. } 2020 \\
{[10]}\end{array}$ & $\begin{array}{l}\text { Cross- } \\
\text { sectional } \\
\text { observational }\end{array}$ & $\begin{array}{l}-1,425 \\
\text { pregnant } \\
\text { women }\end{array}$ & India & $\begin{array}{l}\text {-Infection, } \\
\text { infestations, and } \\
\text { sexually transmitted } \\
\text { diseases } 53.5 \%\end{array}$ & $\begin{array}{l}{ }^{*} \text { Pathological dermatoses }(19.29 \%) \text {, Infection, } \\
\text { infestations and sexually transmitted diseases } \\
(53.5 \%) \text {, pregnancy-specific dermatoses }(24.7 \%) \text {, } \\
\text { acne and folliculitis }(7.6 \%) \text {, non-specific itching } \\
(5.8 \%) \text {, other conditions }(10.9 \%){ }^{*} \text { A knowledge of } \\
\text { the profile of dermatoses during pregnancy is } \\
\text { essential to plan preventive measures, care of the } \\
\text { mother and the child }\end{array}$ \\
\hline \multirow[t]{2}{*}{$\begin{array}{l}\text { Agarwal et } \\
\text { al. } 2020 \text { [11] }\end{array}$} & Retrospective & $\begin{array}{l}-308 \text { pregnant } \\
\text { women }\end{array}$ & India & $\begin{array}{l}\text {-Pigmentary changes } \\
97.35 \%\end{array}$ & $\begin{array}{l}\text { * } 98.05 \% \text { presented with physiological skin } \\
\text { changes of pregnancy; pigmentary changes } \\
(97.35 \%){ }^{*} 38.31 \% \text { had pregnancy-specific } \\
\text { dermatosis, } 60.06 \% \text { had pregnancy non-specific } \\
\text { dermatosis. }{ }^{*} \text { The most common pregnancy- } \\
\text { specific dermatosis was atopic eruption }(44.8 \%) \text {, } \\
\text { polymorphic eruption of pregnancy }(32.2 \%){ }^{*} \text { In } \\
\text { non-specific dermatoses, infectious diseases } \\
\text { were more common * Lower socioeconomic } \\
\text { strata and overcrowding may be the reasons } \\
\text { behind a large number of infectious dermatoses } \\
\text { that we saw in our study. }\end{array}$ \\
\hline & & & & & $\begin{array}{l}{ }^{*} 100 \% \text { had physiological skin changes of } \\
\text { pregnancy }{ }^{*} \% \text { had specific dermatoses of } \\
\text { pregnancy; } 2 \% \text { cases had Pruritic Urticarial } \\
\text { Papules and Plaques of Pregnancy }{ }^{*} 14 \% \\
\text { presented with other dermatoses associated with } \\
\text { pregnancy }{ }^{*} \text { The most common infectious }\end{array}$ \\
\hline
\end{tabular}




\section{Cureus}

\begin{tabular}{|c|c|c|c|c|c|}
\hline $\begin{array}{l}\text { Sharma et } \\
\text { al. } 2019 \text { [12] }\end{array}$ & ---- & $\begin{array}{l}-100 \text { pregnant } \\
\text { women }\end{array}$ & India & $\begin{array}{l}\text {-All women } \\
\text { experienced } \\
\text { physiological skin } \\
\text { changes of } \\
\text { pregnancy; } \\
\text { hyperpigmentation } \\
\text { with linea nigra 82\% }\end{array}$ & $\begin{array}{l}\text { dermatosis affected by pregnancy in this study } \\
\text { group was vulvovaginal candidiasis ( } 5 \text { cases). } \\
\text { * } 82 \% \text { hyperpigmentation with linea nigra, followed } \\
\text { by } 68 \% \text { changes of connective tissue (steriae } \\
\text { gravidarum) }{ }^{*} \text { Skin changes are common during } \\
\text { pregnancy and are usually benign and self- } \\
\text { limiting. Pregnancy specific dermatoses though } \\
\text { few are symptomatic can be associated with } \\
\text { severe fetal outcomes such as fetal distress, } \\
\text { stillbirth, and premature birth *Differentiating } \\
\text { physiological skin changes of pregnancy from } \\
\text { pregnancy-specific dermatosis/ other disease } \\
\text { conditions can avoid unnecessary investigations } \\
\text { and management and aid in better patient care } \\
\text { and counseling }\end{array}$ \\
\hline $\begin{array}{l}\text { EIFaituri } \\
2019 \text { [13] }\end{array}$ & Prospective & $\begin{array}{l}-200 \text { pregnant } \\
\text { women }\end{array}$ & Libya & $\begin{array}{l}\text {-Physiological skin } \\
\text { changes; } 17 \%\end{array}$ & $\begin{array}{l}\text { * } 71 \% \text { coincidental or alteration in pre-existing } \\
\text { diseases, } 17 \% \text { physiological changes, } 12 \% \\
\text { specific dermatoses }{ }^{*} 54 \% \text { of pregnancy } \\
\text { dermatoses occurred during the third trimester } \\
{ }^{*} \text { Hyperpigmentation and strieagravidarum } \\
\text { represented the main physiological changes } \\
(17 \%) .{ }^{*} \text { Specific pregnancy dermatoses were } \\
\text { present in } 12 \% \text {, these were intrahepatic } \\
\text { cholestasis of pregnancy ( } 4 \%) \text {, an atopic eruption } \\
\text { of pregnancy ( } 3 \%), \text { pemphigoid gestationis }(3 \%) \\
\text { and polymorphic eruption of pregnancy }(2 \%) \text {. } \\
{ }^{*} \text { Fetal complications including fetal mortality were } \\
\text { reported with pemphigoid gestationis }(30 \%) \text { and } \\
\text { intrahepatic cholestasis of pregnancy }(25 \%) \text {. } \\
\text { *Most of the reported pregnancy dermatoses were } \\
\text { benign with no adverse effect on the fetus. } \\
\text { Pemphigoid gestationis and intrahepatic } \\
\text { cholestasis of pregnancy can be a source of } \\
\text { significant fetal risk. }\end{array}$ \\
\hline $\begin{array}{l}\text { Chakraborty } \\
\text { et al. } 2019 \\
\text { [14] }\end{array}$ & $\begin{array}{l}\text { Cross- } \\
\text { sectional }\end{array}$ & $\begin{array}{l}-400 \text { pregnant } \\
\text { women with } \\
\text { cutaneous } \\
\text { manifestations }\end{array}$ & India & $\begin{array}{l}\text {-All patients } \\
\text { experienced } \\
\text { physiological } \\
\text { changes; Linea nigra } \\
(86.8 \%)\end{array}$ & $\begin{array}{l}\text { *Most common pigmentary changes; Linea nigra } \\
(86.8 \%) \text {, areolar hyperpigmentation }(68.2 \%) \text {, } \\
\text { melasma }(29.5 \%){ }^{*} \text { Most common connective } \\
\text { tissue changes; striae gravidarum }(75.2 \%){ }^{*} 8.75 \% \\
\text { specific dermatoses; prurigo of pregnancy }(8 \%) \\
\text { followed by pruritic urticarial papules and plaques } \\
\text { of pregnancy }(0.5 \%) \text {. } 36.75 \% \text { Non-specific } \\
\text { dermatoses; The commonest was dermatophyte } \\
\text { infection *Prurigo of pregnancy was more } \\
\text { frequently recorded in multigravida patients and } \\
\text { more frequently in the third trimester of pregnancy } \\
\text { * the specific dermatoses of pregnancy, which are } \\
\text { not a rare entity, can be a source of significant } \\
\text { distress to the pregnant female and need timely } \\
\text { therapeutic intervention *Physicians should } \\
\text { distinguish between physiological skin changes } \\
\text { and specific dermatoses of pregnancy for better } \\
\text { patient care }\end{array}$ \\
\hline $\begin{array}{l}\text { Bangaru et } \\
\text { al. } 2019[15]\end{array}$ & $\begin{array}{l}\text { Prospective } \\
\text { cross- } \\
\text { sectional }\end{array}$ & $\begin{array}{l}-700 \text { pregnant } \\
\text { women }\end{array}$ & India & $\begin{array}{l}\text {-All pregnant } \\
\text { experienced } \\
\text { physiological skin } \\
\text { changes; Linea nigra } \\
(87.14 \%)\end{array}$ & $\begin{array}{l}{ }^{*} \text { Physiological skin changes; } 87.14 \% \text { Linea nigra } \\
{ }^{*} 8.28 \% \text { Specific dermatoses; }(62.06 \%) \text { atopic } \\
\text { eczema, }(31.03 \%) \text { pruritic urticarial papules and } \\
\text { plaques of pregnancy }{ }^{*} \text { Many skin changes that } \\
\text { occur during pregnancy are physiological require } \\
\text { no treatment. "Knowledge about pregnancy } \\
\text { specific dermatoses is necessary as dermatoses } \\
\text { specific to pregnancy can affect the pregnancy } \\
\text { and the fetus }\end{array}$ \\
\hline & & & & & $\begin{array}{l}\text { * } 98 \% \text { had physiological changes; }(94.49 \%) \text { had } \\
\text { hyperpigmentation, }(88.5 \%) \text { had linea nigra, }\end{array}$ \\
\hline
\end{tabular}




\section{Cureus}

\begin{tabular}{|c|c|c|c|c|c|}
\hline $\begin{array}{l}\text { Meena \& } \\
\text { Gehlot } 2018 \\
{[16]}\end{array}$ & $\begin{array}{l}\text { Observational } \\
\text { cross- } \\
\text { sectional }\end{array}$ & $\begin{array}{l}-200 \text { pregnant } \\
\text { women }\end{array}$ & India & $\begin{array}{l}\text {-Physiological } \\
\text { changes }(98 \%) ; \\
\text { hyperpigmentation } \\
(94.49 \%)\end{array}$ & $\begin{array}{l}(76.5 \%) \text { had striae distensae, }(53.5 \%) \text { had } \\
\text { secondary areola * } 5 \% \text { had specific dermatoses; } \\
(5 \%) \text { had pruritic urticarial papules and plaques of } \\
\text { pregnancy, }(2 \%) \text { had pruritic folliculitis, }(2 \%) \text { had } \\
\text { eczema *Pregnant women are prone to various } \\
\text { cutaneous manifestation during pregnancy. A } \\
\text { detailed history and awareness of clinical } \\
\text { presentation is helpful for confirmation of } \\
\text { diagnosis and most appropriate laboratory } \\
\text { evaluation is helpful to diminish the maternal and } \\
\text { fetal morbidity }\end{array}$ \\
\hline $\begin{array}{l}\text { Panicker et } \\
\text { al. } 2017 \text { [17] }\end{array}$ & $\begin{array}{l}\text { Observational } \\
\text { cross- } \\
\text { sectional }\end{array}$ & $\begin{array}{l}-600 \text { pregnant } \\
\text { women }\end{array}$ & India & $\begin{array}{l}\text {-Physiological } \\
\text { changes }(99 \%) ; \\
\text { hyperpigmentation } \\
(87.6 \%)\end{array}$ & $\begin{array}{l}{ }^{*} \text { Physiological changes } 99 \% \text {; hyperpigmentation } \\
(87.6 \%) \text {, striae gravidarum }(72.8 \%),{ }^{*} 2 \% \text { Specific } \\
\text { dermatoses the most common being pruritic } \\
\text { urticarial papules and plaques of pregnancy } \\
(1.3 \%){ }^{*} \text { Pregnant women are prone to suffer from } \\
\text { a wide range of dermatological problems apart } \\
\text { from specific dermatoses of pregnancy }\end{array}$ \\
\hline $\begin{array}{l}\text { Fernandes } \\
\text { \& Amaral } \\
2015[18]\end{array}$ & $\begin{array}{l}\text { Cross- } \\
\text { sectional }\end{array}$ & $\begin{array}{l}-905 \text { pregnant } \\
\text { women }\end{array}$ & Brazil & $\begin{array}{l}\text {-Physiological skin } \\
\text { changes }(88.95 \%) \text {; } \\
\text { Linea nigra }(54.75 \%)\end{array}$ & $\begin{array}{l}\text { * Physiological skin changes }(88.95 \%) \text {; Linea nigra } \\
(54.75 \%) \text {, Melasma }(54.03 \%) \text { stretch marks } \\
(46.96 \%){ }^{*} 8.72 \% \text { specific dermatoses; atopic } \\
\text { eruption }(70.88 \%) \text { * Physiological changes were } \\
\text { seen more in the 3rd quarter, as well as the } \\
\text { specific dermatoses }\end{array}$ \\
\hline
\end{tabular}

TABLE 1: Summary of included studies

Physiological skin changes are the predominantly recognized dermatologic manifestations of pregnancy as eight studies reported [11-18], three of which discovered that all included pregnant women had physiological skin changes $[12,14,15]$. On the other hand, these physiological changes varied in prevalence in two different studies, which showed a range of $17 \%$ [13] to 99\% [17]. Pregnancy-related abnormal skin pigmentation is the most recognized physiological dermatologic-related sign during pregnancy $(87.6 \%$ 98.05\%) [16,17], followed by hyperpigmentation with linea nigra (82\%) [12], linea nigra (54.75\%-87.14\%) [15,17], striae gravidarum or stretch marks $46.96 \%$ [17] to $2.8 \%$ [18], and melasma (54.03\%) [18].

Dermatosis of pregnancy or pregnancy-specific dermatosis is a major cause of morbidity during pregnancy and its prevalence has ranged from $2 \%$ [12,17] to $40.85 \%$ [8], whereas one study [9] reported that these pregnancy-specific dermatoses can affect up to $85.5 \%$ of pregnant women. Dermatosis specific to pregnancy included mainly, but not limited to, prurigo of pregnancy (8\%-47.12\%) [8,14], pruritic urticarial plaques, and papules of pregnancy $(0.5 \%-43.93 \%)[8,14]$, and atopic eruption of pregnancy $(4 \%-72.72 \%)[9,13]$.

\section{Discussion}

During pregnancy, several changes occur to optimize fetal and maternal well-being which should eventually result in the delivery of a healthy baby, these changes include changes in the function of the endocrine system to regulate the various hormone secretions, immune system, and the various metabolic pathways that ensure delivery of nutrients and metabolic fuel to the fetus. Some of these changes contribute to a spectrum of physiological and pathological physical changes seen during pregnancy, such as the development of various skin conditions [4]. In the current systematic review, we found that skin pigment disorders account for the most common physiological skin conditions in gravid women, whereas atopic eruptions were the major dermatoses specific to pregnancy.

Physiological dermatological changes in pregnancy involve pigmentary changes such as hyperpigmentation, which occurs among $90 \%$ of pregnant women. It usually occurs in a localized area and may be due to the regional differences in the density of melanocytes within the epidermal layer of the skin. However, generalized hyperpigmentation can occasionally occur $[19,20]$. A dark line that forms from the mid suprapubic area to the umbilicus called linea nigra is a common finding in pregnant women as well [4]. Melasma, which is known as the mask of pregnancy, is a common, pregnancy-specific pigmentation caused by excess estrogen. It is more obvious in women with darker skin tones and occurs in topographical areas such as cheeks, upper lip, and forehead. It mostly appears in the second trimester of pregnancy [21] and can affect up to $50 \%$ to $70 \%$ of women [22]; in this systematic review, however, only one study [18] reported that half of the pregnant women experienced melasma. Though some studies have shown that these pigmentary lesions could affect a wide range of pregnant women $[13,17]$, The prevalence of such pigmentary skin lesions during pregnancy can truly vary depending on various factors, but some studies have reported that almost 
Besides pigmentary changes, striae gravidarum or stretch marks are common structural skin changes commonly seen in pregnancy due to the rapid change in weight and the effects of elevated hormones on the integrity of collagen and other skin constituents [17,18]. Striae gravidarum are structural skin changes, and they occur in up to $90 \%$ of pregnant women in the third trimester [21,23]. They occur commonly at the lower abdomen as the connective tissue beneath the skin tear during pregnancy due to excessive stretch, which helps accommodate the rapidly growing fetus [4].

Dermatoses specific to pregnancy are skin pathologies that commonly occur in pregnancy or exacerbations of pre-existed dermatologic diseases seen in gravid women. The most common pregnancy-specific dermatosis was the atopic eruption of pregnancy which was seen in $4 \%$ to $72.72 \%$ of women with pregnancy-associated dermatosis $[9,13]$ and it was also reported in other four studies as well but with lower frequency $[9,11,13,18]$. Prurigo of pregnancy can be considered in the second rank as it has been reported in up to $47 \%[8,14]$, and there were two studies that reported the presence of this condition $[8,14]$. In the third rank, pruritic urticarial plaques and papules of pregnancy have a range between $0.5 \%$ and $43.93 \%[8,14]$.

Atopic eruption of pregnancy is a benign pruritic condition that is characterized by popular lesions or eczema in patients with a history of atopic dermatitis or predisposition to atopic dermatitis or even with new-onset atopic dermatitis during pregnancy. Its prevalence was stated to be in the range of 5\%-20\% [5]; however, the included studies reported a much higher prevalence (4\%-72.72\%). Prurigo of pregnancy belongs to the pregnancy-specific dermal diseases and this condition involves different variants; the mild and most common variant, which is characterized by localized lesions only, and the generalized variant, which is known as popular dermatitis [3]. Pruritic urticarial plaques and papules of pregnancy are other pregnancy-specific dermatological diseases. It is a pruritic inflammatory cutaneous disease with an incidence of one in 160 pregnant women [24]. Although it was reported that Pruritic urticarial plaques and papules of pregnancy are the most common pregnancy-specific dermatoses [24], the current systematic review showed that atopic eruption was the most common dermatoses specific to pregnancy.

This systematic review has few limitations, such as the majority of the studies included were from India; however, these studies were included as they met the inclusion criteria.

\section{Conclusions}

Pregnant women are more prone to several cutaneous conditions during pregnancy, such as physiological skin changes, pregnancy-specific dermatoses, and flares of pre-existing chronic skin conditions. The most common physiological skin changes are hyperpigmentary changes, whereas atopic eruption is the most common dermatoses form. Eczematous eruptions have been the most common exacerbation of a chronic skin condition during pregnancy. These pathological skin conditions can be a source of considerable distress to pregnant women and may warrant immediate interventions, though their diagnosis and management can be challenging and require a thorough knowledge of their different presentations and special treatments to ensure maternal and fetal safety. Therefore, a physician's knowledge about the profile of these various dermatoses during pregnancy is necessary in order to plan preventive measures and provide comprehensive care for the mother and her baby.

\section{Additional Information \\ Disclosures}

Conflicts of interest: In compliance with the ICMJE uniform disclosure form, all authors declare the following: Payment/services info: All authors have declared that no financial support was received from any organization for the submitted work. Financial relationships: All authors have declared that they have no financial relationships at present or within the previous three years with any organizations that might have an interest in the submitted work. Other relationships: All authors have declared that there are no other relationships or activities that could appear to have influenced the submitted work.

\section{References}

1. Karen J, Pomeranz M: Skin changes and diseases in pregnancy. Fitzpatrick's Dermatology in General Medicine. Goldsmith LA, Fitzpatrick TB, Katz SI, Gilchrest BA, Paller A, Wolff K, Leffell DJ (ed): McGraw-Hill Education, New York, NY; 2012. 1204:1212.

2. Jones SV, Ambros-Rudolph C, Nelson-Piercy C: Skin disease in pregnancy. BMJ. 2014, 348:g3489. 10.1136/bmj.g3489

3. Ambros-Rudolph CM: Dermatoses of pregnancy - clues to diagnosis, fetal risk and therapy . Ann Dermatol. 2011, 23:265-75. 10.5021/ad.2011.23.3.265

4. Hassan T, Mohsena M, Sultana A, Khondker L, Islam S, Sultana R: Pregnancy related skin changes and skin diseases. Bangladesh Med J. 2016, 44:112. 10.3329/bmj.v44i2.27256

5. Sävervall C, Sand FL, Thomsen SF: Dermatological diseases associated with pregnancy: pemphigoid gestationis, polymorphic eruption of pregnancy, intrahepatic cholestasis of pregnancy, and atopic eruption of pregnancy. Dermatol Res Pract. 2015, 2015:979635. 10.1155/2015/979635 
6. Burgdorf W, Plewig G, Wolff HH, Landthaler M: Braun-Falco s Dermatology. Springer, Berlin; 2008.

7. Liberati A, Altman DG, Tetzlaff J, et al.: The PRISMA statement for reporting systematic reviews and metaanalyses of studies that evaluate health care interventions: explanation and elaboration. PLoS Med. 2009, 6:e1000100. 10.1371/journal.pmed.1000100

8. Deora A, Bijarnia R, Desai R, Kachhawah D: Clinical study of pregnancy specific dermatoses- an observational study at tertiary care centre of Western Rajasthan. Int J Health Clin Res. 2021, 4:127-30.

9. Ayanlowo O, Otrofanowei E, Shorunmu T, Adegbola O: Pregnancy dermatoses - a study of patients attending antenatal clinic at two tertiary care centers in south west Nigeria. PAMJ Clin Med. 2020, 3:156. 10.11604/pamj-cm.2020.3.156.23602

10. Choudhary A, Saxena K, Koti V, Ansari A, Yadav S, Hans T: Clinical evaluation of pathological dermatoses induced in pregnancy. Int J Res Dermatol. 2020, 6: 10.18203/issn.2455-4529.IntJResDermatol20200506

11. Agarwal P, Chaudhari S, Jagati A, Rathod S, Neazee S: Clinical spectrum of pregnancy related dermatoses in a tertiary care hospital in western India. Natl J Community Med. 2020, 11:450-5. 10.5455/njcm.20201218045901

12. Sharma A, Jharaik H, Sharma R, Chauhan S, Wadhwa D: Clinical study of pregnancy associated cutaneous changes. Int J Clin Obstet Gynaecol. 2019, 3:71-5. 10.33545/gynae.2019.v3.i4b.292

13. Elfaituri S: Dermatoses of pregnancy. A prospective study from Benghazi, Libya . J Dermatol Cosmetol. 2020, 3:152-5. 10.15406/jdc.2019.3.00134

14. Chakraborty A, Wankhade V, Supekar B, Chopkar A, Singh R: Dermatological changes in pregnancy in central India: a cross sectional study. Int J Res Dermatol. 2019, 5:411. 10.18203/issn.24554529.IntJResDermatol20191771

15. Bangaru H, Sudha R, Lingaiah NB, Sathish S, Surendran K: Cutaneous changes in pregnancy: a comprehensive study of 700 cases at a tertiary care centre from South India. IP Indian J Clin Exp Dermatol. 2019, 5:249-54. 10.18231/j.ijced.2019.053

16. Meena M, Gehlot H: A clinical study of skin disorders in pregnancy . Int J Reprod Contracept Obstet Gynecol. 2018, 7:715-8. 10.18203/2320-1770.ijrcog20180200

17. Panicker VV, Riyaz N, Balachandran PK: A clinical study of cutaneous changes in pregnancy . J Epidemiol Glob Health. 2017, 7:63-70. 10.1016/j.jegh.2016.10.002

18. Fernandes LB, Amaral WN: Clinical study of skin changes in low and high risk pregnant women . An Bras Dermatol. 2015, 90:822-6. 10.1590/abd1806-4841.20153570

19. Martin AG, Leal-Khouri S: Physiologic skin changes associated with pregnancy. Int J Dermatol. 1992, 31:3758. 10.1111/j.1365-4362.1992.tb02662.x

20. Kumari R, Jaisankar TJ, Thappa DM: A clinical study of skin changes in pregnancy . Indian J Dermatol Venereol Leprol. 2007, 73:141. 10.4103/0378-6323.31910

21. Kroumpouzos G, Cohen LM: Dermatoses of pregnancy. J Am Acad Dermatol. 2001, 45:1-19; quiz 19-22. 10.1067/mjd.2001.114595

22. Winton GB, Lewis CW: Dermatoses of pregnancy. J Am Acad Dermatol. 1982, 6:977-98. 10.1016/s01909622(82)70083-0

23. Wong RC, Ellis CN: Physiologic skin changes in pregnancy. J Am Acad Dermatol. 1984, 10:929-40. 10.1016/s0190-9622(84)80305-9

24. Charles-Holmes R: Polymorphic eruption of pregnancy. Semin Dermatol. 1989, 8:18-22. 